\title{
NEWS FROM FOREIGN RESEARCH INSTITUTES
}

[Excerpted from Rural Development Network Bulletin, No. 6, Part I, July 1976, special issue on "Women in Rural Development," guest edited by Joyce Mortimer.]

AFRICAN TRAINING AND RESEARCH CENTRE FOR WOMEN (ATRCW). ATRCW was launched in March, 1975, as a result of the work of the Women's Programme Unit of the United Nations Economic Commission for Africa (UNECA) established in 1971 in Addis Ababa. Most of the training activities of the Centre will take place in OAU-member countries rather than at the Centre itself.

The Centre provides: a) formal and apprentice in-service training; b) a volunteer corps network composed largely of skilled African women who serve in countries other than their own; c) applied research on issues deemed most important by the various communities concerned; and d) publication and dissemination of information and resource materials promoting the advancement of women in all sectors of the societies.

ATRCW activities focus on one or more of the following subject areas:

1. Food and Nutrition (including food preparation)

A. Nutrition Policy and Programs

B. Food Distribution, Storage and Preservation

II. Wage Labor
A. Handicrafts
B. Small-Scale Businesses and Industries
C. Upgrading of Wage-Employed Women

III. Family Service Management
A. Management of Family Resources
B. Budgeting
C. Use of Labor-Saving Devices and Home Improvement

IV. In-Service Training of Social Welfare Workers and Supervisors

V. Integration of Women in National and Project Planning

VI. Development of Communication and Organizational Skills

An African Women's Development Fund will be established by UNECA in collaboration with the All Africa Women's Conference and specialized UN agencies to promote the regional activities of the Centre. Funds will be raised from private, governmental and nongovernmental sources. Three types of regional/national organizations have been established to facilitate the Centre's work:

1) Nationals Commissions on Women and Development-composed of leading men and women who would advance policy recommendations and action proposals;

2) Women's Bureaux or Permanent Secretariats of National Commissions-charged with designing research project and program formulations, and assuring women's integration in all sectors of economic and social development;

3) African Regional Standing Committee-charged with coordination of the work of the National Commissions, advising the Centre and maintaining contact with international and regional organizations.

ATRCW published a quarterly newsletter, African Women, as well as country reports (thirty-nine to date) on vocational opportunities for women. The Centre has also been compiling information on farm and home village technology and is preparing a handbook for rural workers.

In addition to donations from organizations, foundations and individuals, the ATRCW would appreciate gifts of documents related to women in the developing world. Readers wishing to be placed 
on the mailing list for publications or wishing to donate publications should write to: UNECA, African Training and Research Centre for Women, P.O. Box 3001 or 3005, Addis Ababa, Ethiopia.

[Excerpted from Africana, Vol. 1, No. 1. Bi-monthly newsletter of the Council for the Development of Economic \& Social Research in Africa (B.P. 3304, Dakar, Senegal).]

THE U.N. INSTITUTE FOR NAMIBIA (Director Hage G. Geingob) was created by decision of the United Nations General Assembly "to enable Namibians, under the aegis of the United Nations Council for Namibia, to undertake research, training, planning and related activities with special reference to the struggle for freedom of the Namibians and the establishment of an independent State of Namibia." At present located in Zambia, it will be moved to Namibia "immediately after the termination of the illegal occupation of the territory and handed over to the government of independent Namibia." Research and training covers a wide field: history, politics, agriculture, economics, social and educational affairs, constitutional, legal and judicial problems. The Institute is open only to students of Namibian origin, but its teaching and research staff are recruited from a range of organizations and countries. For further information, write: The U.N. Institute for Namibia, P.O.B. 3011 , Lusaka, Zambia.

INSTITUT DE FORMATION ET DE RECHERCHE DEMOGRAPHIQUES, the francophone counterpart of the Regional Institute for Population Studies in Accra, was set up in Yaounde, following an agreement between the United Nations and the government of Cameroon, and first opened its doors to trainees from twenty-two African francophone countreis in 1972. The Institute undertakes fundamental and applied research into population trends, provides consultative services on request and organizes a two-year course for high-ranking civil servants. This course is open to statisticians, geographers, sociologists, economists, mathematicians who hold a university degree or equivalent diploma.

Contact: IFORD, B.P. 1556, Yaounde, Cameroun.

CENTER FOR THE COORDINATION OF SOCIAL SCIENCE RESEARCH AND DOCUMENTATION IN AFRICA SOUTH OF THE SAHARA (CERDAS). This center is based in Kinshasa, Zaire, at UNZA and its acting Director is Professor Mpekesa Bongoy.

In 1972, UNESCO's General Conference adopted a resolution to set up CERDAS. The Center was however actually set up in September 1974 when an agreement was signed between UNESCO and Zaire. The Center is an inter-governmental body whose creation and development is being supported by UNESCO.

"The functions of the Center are to promote regional cooperation between institutions of social science research and documentation in Africa south of the Sahara, and to contribute to the development of these disciplines throughout the region."

For more information, write: Professor M. Bongoy, Box 836, Kinshasa X1, Zaire.

THE AFRICAN INSTITUTE FOR ECONOMIC DEVELOPMENT AND PLANNING (I.D.E.P.), Dakar, Senegal, organized the following seminars and conferences during 1976.

1. A National Seminar in Ethiopia. Theme: "Agrarian Reform and the National Economic Order in Ethiopia and Their Implications for Development Planning." Conference coordinator: Dr. AttaMills.

2. A National Seminar in Madagascar. Theme: "An Appraisal of the Planning Experience and Strategies in Madascar." June 1976. Conference coordinator: Mr. Founou.

3. Conference on Afro-Arab Cooperation. This conference was jointly sponsored by I.D.E.P. and the Arab Planning Institute and was held in Khartoum, November 1976. Mr. Samba Sow of I.D.E.P. coordinated the conference.

4. Conference on the Use of Oil and Other Raw Material Revenues for the Purposes of Internal Development. This conference, which complements the one on Afro-Arab cooperation, was held in Libya, September 1976.

5. The FAO/IDEP Conference on Agricultural Planning and Sectorial Analyses. This conference was held at IDEP's premises, in Dakar, between November 19 and December 18, 1976. 


\section{DRODAT: (Drought Data)}

This planning workshop was held at I.D.E.P. headquarters in Dakar, Senegal from April 28-May 3 , 1976. The workshop brought together African researchers and policy-makers as well as representatives of various international research institutes and agencies concerned with reducing the effects of the drought.

The Drodat Project was sponsored by IRSH, Niamey, ENDA, Dakar, and Clark University, U.S.A. It was funded by IDRC.

The workshop recommended that the Drodat Program

a) Should consist of a network of African research institutes undertaking research in arid zones.

b) Two African research institutes-CIVRES in Ouagadougou and BRALUP in Dar-es-Salaam should be the focal and coordinating institutes for the Program lone for the Sahel and West Africa and one for Eastern Africa).

c) CODESRIA provides clearing house and other functions in order to facilitate the effective operation of the program.

d) An evaluative review of past research on drought, famine and development, should immediately be organized through well prepared workshops. At the same time, action oriented research should be undertaken in strategic issues-areas.

The Environment Programme of IDEP held the following training workshops during 1976.

1. Environment of mountainous areas with high population density. Bukavu, Zaire. October, 1976.

2. Women and development. Dakar, Senegal. November, 1976.

3. Administration and environment. Tangier. September 1976.

4. Rural environment and development in southern Africa. July 1976.

THE COUNCIL FOR ECONOMIC AND SOCIAL RESEARCH IN AFRICA (CODESRIA) was established as a clearing house for information on continent-wide activities, research and publications in the field of economic and social research. The representatives of many African universities and research institutes who took this decision at the inaugural meeting of CODESRIA in Dakar, on 1 February 1973, did so in response to a clearly-felt need to organize social sciences for the social and economic development of the continent. In this connection, a lead has already been given by Latin American social scientists and CODESRIA's sister organization CLACSO (Latin American Council for Social Sciences), who had already seriously challenged orthodox development theory and built up a considerable body of research into the development process.

In Africa, CODESRIA seeks to stimulate both fundamental and problem-oriented research and to further this challenge to theories which have led not only to stagnation but to regression and further underdevelopment. To this end, CODESRIA is building bridges across language barriers, defining priorities and organizing African social scientists into collaborative research teams. It is also, in accordance with its charter, promoting collaboration in training activities between research institutes in Africa and with those outside the continent, commissioning or promoting translations of major publications existing in only one language and, of course, disseminating information.

Top priority, however, is given to the collaborative and interdisciplinary research projects, for obvious reasons. The process starts with the organization of small workshops, for which specific financing is sought. A number of team leaders are selected by the CODESRIA Executive Committee, covering different disciplines, and coming from both Anglophone and Francophone countries, who are subsequently responsible for organizing the work of the collaborative teams. Two groups, on rural development and on the sociology of development, co-sponsored with CERDAS, were set up in 1973 and their research efforts are well advanced. In 1974, a conference on Population Policy and Economic Development recommended the establishment of five groups and research projects. These projects are at different stages of development. A Workshop on Population, Resources and Environment in West Africa was held in 1975; Youth Attitudes to Development in Senegal and Gambia are 
being studied by a group created in 1974, and initial steps have been taken to set up one on Size, Structure and Growth of the Labour Force in Africa. Other projected groups for which funding is being sought include International Migration in West Africa, and Vital Statistical Registration in Africa, which is to be linked to improvement of existing national statistical centres. The first workshop meeting on Interdisciplinary Approach to Development Planning was held in November 1975 and proposed, as a priority project, the production of a book on Interdisciplinary Teaching in Higher Education. The CODESRIA 1976 General Assembly is to be combined with a conference on Industrialization and Income Distribution. Other plans for 1976 include Workshops on Economic Cooperation and Integration in Africa, Monetary Problems in Africa, Special Problems of the Land. locked and Least Developed Countries and, of major interest, Africa and the New International Economic Order.

In 1976 CODESRIA began publication of a bi-monthly newsletter Africana distributed free of charge to about 225 African training and research centers and to more than 100 institutes outside Africa. Please airmail all communication to the Executive Secretary, C.O.D.E.S.R.I.A., B.P. 3304, Dakar, Senegal.

Other major activities include the operation of a data bank and regular publication of the information it provides in Africa Development Research Annual; a quarterly journal. Africa Development, containing in-depth analyses, articles, etc. and a book series on working group research and seminar papers.

\section{RESULTS OF THE BOARD OF DIRECTOR'S RESOLUTION OF APRIL 2, 1976}

The African Studies Association condemns the participation of scholars in clandestine intelligence operations. The African Studies Association condemns the clandestine use or employment of scholars by the intelligence agencies and calls upon Africanist scholars to take no part in such activities.

396-approve; 37-disapprove.

VISITING AFRICAN LECTURERS AND RESEARCH SCHOLARS

(in the Humanities, Social Sciences, and Education) IN THE UNITED STATES UNDER THE

MUTUAL EDUCATIONAL EXCHANGE PROGRAM (FULBRIGHT-HAYS ACT) 1976-77

NAME, HOME INSTITUTION

AGIRI, Babatunde A.

Senior Lecturer in History

University of Lagos

Lagos, Nigeria

LIMAM, Rached

Associate Professor of History

University of Tunisia

Tunis
HOST INSTITUTION, DURATION OF STAY

University of Wisconsin-Madison African Studies Program 10/76-3/77

Library of Congress Washington, D.C. 6/77-9/77
PROJECT IN THE U.S.

Socio-economic history, rural development (reading); Socioeconomic-cultural changes in Nigeria, American studies in Africa (lecturing)

Economic \& diplomatic relations between Tunisia \& the United States, 1782-1814 (reading) 